\title{
Children-Engaging Social and Environmental Initiatives as Determinants of Corporate Reputation
}

\author{
Ingrida Šmaižienè
}

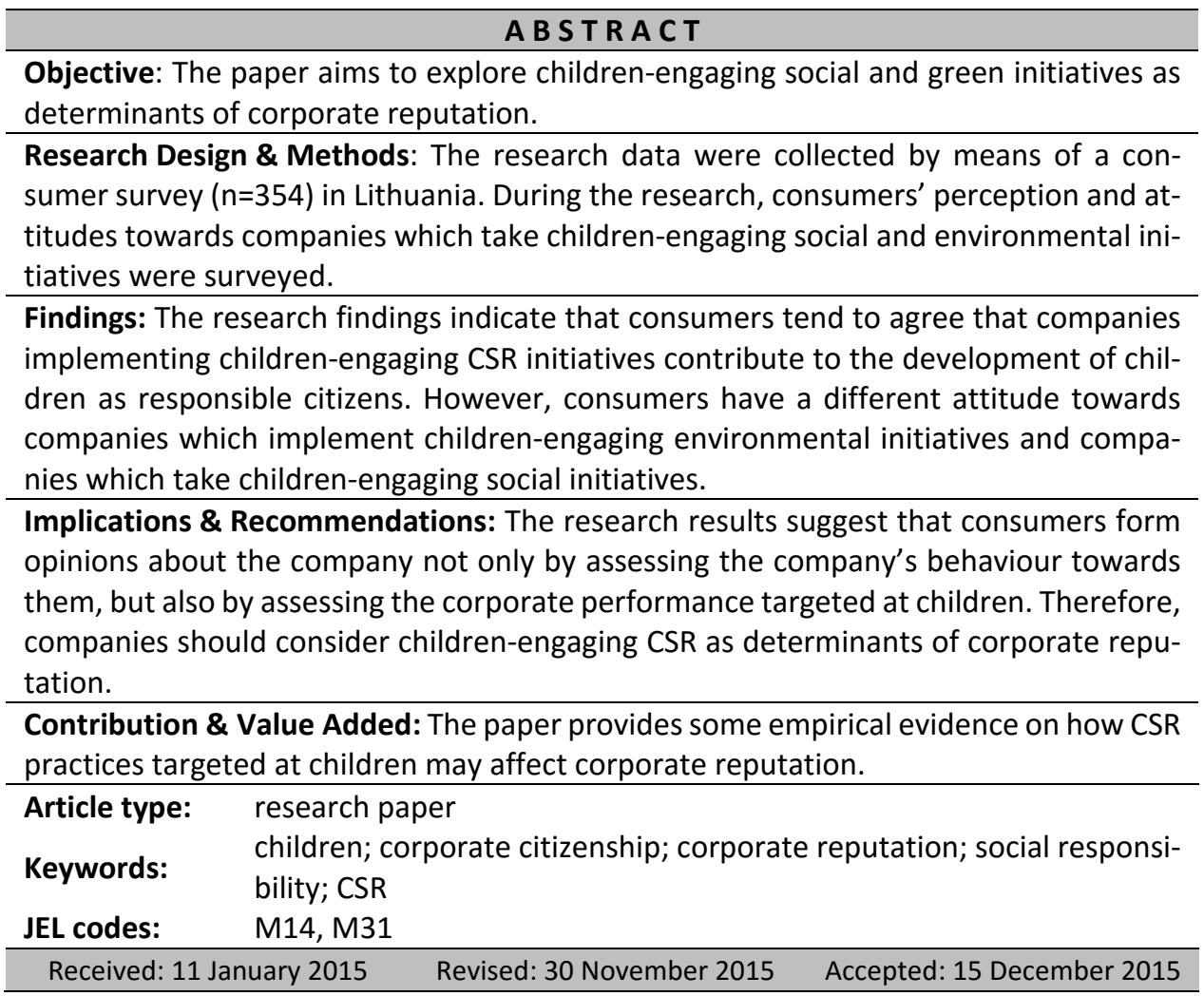

\section{Suggested citation:}

Šmaižienè, I. (2015). Children-Engaging Social and Environmental Initiatives as Determinants of Corporate Reputation. Entrepreneurial Business and Economics Review, 3(4), 89-103, DOI: http://dx.doi.org/10.15678/EBER.2015.030406 


\section{INTRODUCTION}

Corporate reputation management encompasses both economic and social (normative or moral) practices (Smaiziene \& Jucevicius, 2013). Thus, corporate social responsibility (CSR) gains special attention in the field of corporate reputation management. CSR is referred to as a dimension or a determinant of corporate reputation by a number of scholars (Hillenbrand \& Money, 2007; Lynes \& Andrachuk, 2008; Smaiziene \& Jucevicius, 2009; Bartikowski \& Walsh, 2011; Maden et al., 2012; Mehtap \& Kokalan, 2012). In the field of academic research, more and more research is conducted not only to theoretically explain the relationship between the concepts of corporate social responsibility and corporate reputation but also to substantiate the relationship empirically.

Despite a common view of positive returns of investment in social responsibility, some of the statements about the benefits of social responsibility lack empirical evidence (Castaldo et al., 2009). The questions of how the corporate signals of social and environmental responsibility activity and achievements are perceived in different stakeholder groups, and how the perception leverages corporate reputation are still open (Arendt \& Brettel, 2010).

As any other corporate social responsibility (CSR) activity, CSR initiatives targeted at children can provide not only functional, but also social and emotional value to consumers (Green \& Peloza, 2011) and other stakeholders, and serve as a booster of corporate reputation. Therefore, children-engaging social and environmental initiatives are considered to be corporate reputation management tools used for shaping public opinion about the company as a good citizen.

Children-related CSR activities might be observed in the market and/or found in the reports on CSR (i.e. the contest of children drawings 'Save the Baltic Sea' organised by firms, the social initiative 'Return an Unnecessary Toy' during which children were invited to give their unused toys to children care homes, etc.). Despite more frequent manifestation of children-engaging social and environmental initiatives in practice, the scientific literature does not pay much attention to the cognition of such initiatives. Children-oriented business practice, including children-engaging CSR initiatives, has received surprisingly little attention in the academic field of corporate reputation management. Moreover, because of children's vulnerability, children-engaging CSR initiatives call for special consideration. Such a kind of initiatives should be treated not only as a determinant of corporate brand development but also as a determinant of corporate reputational risk.

The paper aims at disclosing children-engaging CSR initiatives as determinants of corporate reputation. The following research questions are discussed: what is the consumers' perception and attitudes towards companies which organise and implement children-engaging social initiatives; what is consumers' perception of and attitudes towards companies which organise and perform children-engaging environmental initiatives. The research methods applied are consumer survey $(n=354)$ and statistical analysis.

The paper is structured as follows. The first section discusses the theoretical insights on the topics of CSR as a determinant of corporate reputation and children-engaging social and environmental initiatives as the tools of corporate reputation management. In the second part of the paper, the research logic and methods are presented. Research results are presented and discussed in the third part of the paper. 


\section{LITERATURE REVIEW}

\section{Social and Environmental Initiatives as Determinants of Corporate Reputation}

Results from previous studies suggest that there is a common view that CSR activities send positive signals to the stakeholders and society (Linthisum et al., 2010; Maden et al., 2012). Social responsibility practice is considered a determinant of positive associations and favourability towards a company among consumers, the community and other stakeholders (Pomering \& Johnson, 2009; Lin et al., 2012; Deng et al., 2013). The public opinion, which is formed on the ground of corporate social responsibility activities, is considered to be a part of corporate reputation portfolio (Smaiziene \& Jucevicius, 2013). Via positive social reputation, corporate social responsibility provides indirect economic benefits (Linthisum et al., 2010) and the impact upon the company's competitiveness (Vilanova et al., 2009). Thus, the reputation forming on the basis of the firm's social responsibility activities and achievements - as all reputations of the corporate reputation portfolio - has to be managed purposefully and systematically.

The increasing importance of social responsibility reputation (or social reputation) and a demand to be socially responsible are based on the belief that corporations develop their practice in the environment shared with the society (Gibbs, 2012). Thus, business organisations are responsible not only for pursuing profits and creating value for shareholders, but also for contributing to the common well-being. Previously, it was believed that that companies contribute to societal development by paying taxes (Timonen \& Luoma-aho, 2010). Nowadays, business faces the pressure to produce outcomes broader than economic profits (Tracey et al., 2005; Rego et al., 2010) and contributions bigger than taxes. Stakeholders are more subject to concern what hides under brands, attractive packaging and corporate communication programmes. More and more stakeholders are interested not only in products but also in what companies produce those products (Dawkins, 2004; Pomering \& Johnson, 2009). Socially constructed expectations and the wish that companies would take social role are getting stronger (Shinkle \& Spencer, 2012). As Crittenden et al. (2011) state, modern organisations need social engagement programmes which not only generate social benefits but also enable to reduce business and reputational risk and create market opportunities for competitive advantage.

Initiatives of corporate social responsibility (CSR) are closely related to corporate citizenship paradigm. A modern organisation faces the challenge and the requirement to be a good citizen. Acting as a good citizen means to take volunteer obligations to meet stakeholders' social and environmental expectations beside obligatory economic and legal commitments (Pomering \& Johnson, 2009; Sison, 2009; Babiak \& Trendafilova, 2011; Lin et al., 2012).

It should be admitted that CSR and corporate citizenship meaning, as well as performance are treated very differently, both in the academic field and business practice. In most cases environmental initiatives are considered to be a part of corporate social responsibility. Yet, nowadays, some scientists and practitioners, in order to seek for explicitness, suggest separating the concepts of social responsibility and environmental responsibility (Orlitzky et al., 2011). For example, Lynes and Andrachuk (2008) suggest changing the CSR term (corporate social responsibility) into CSER (corporate social and environmen- 
tal responsibility), which better reflects a company's obligations to act as a socially presponsible and environment friendly player. The voluntary activity of an organisation aimed to increase the welfare of the people inside and outside the organisation should be considered as social initiatives. The voluntary activity of an organisation targeted to natural environment and planet should be considered environmental initiatives (Graafland \& Smid, 2004).

The management of corporate social and environmental reputation involves an organisation 's attempts to be a good citizen and to look as a good citizen in the eyes of stakeholders. In other words, when shaping corporate reputation, a company organises and performs social and green initiatives, as well as communicates them to chosen key stakeholders. Performing and communicating corporate social initiatives are considered to be the instruments for shaping social reputation. Performance and communication of corporate environmental initiatives are regarded to be the instruments for building green (environmental) reputation.

Both social and environmental initiatives distinguish with diversity (Truscott et al., 2009). Corporate social and environmental responsibilities can be expressed through sponsorship, donations, employee education and well-being programs, cause-related marketing, the support for local, national and worldwide social and environmental initiatives, community engagement, etc. The selection of the type of CSR initiatives should be a scrutinised decision because the influence of CSR performance upon an organisation 's reputation varies not only in different groups of stakeholders, but also in applying different instruments of social and environmental activity (Brammer \& Pavelin, 2006; Maden et al., 2012).

After selecting the type of a CSR initiative, another step in building social reputation and green reputation is communication about a company's willingness to act in a social and environment friendly manner and the initiatives being implemented. When communicating social and environmental issues, the creation of the visibility of the company as a socially and environmentally responsible society member and favourability towards it are pursued.

As Veleva (2010) notes, in practice only some organisations communicate their social and environmental initiatives. Most often, the instrument of communicating social and green initiatives is chosen: the company website presents the company's declarations, practice and achievements related to the its involvement in social and environmental issues (Capriotti \& Moreno, 2007). Another way used quite often to send CSR signals are cause-related marketing campaigns.

In the attempts to communicate CSR activities and achievements companies encounter some difficulties and challenges. Traditional ways to communicate social and green responsibility do not work very well (Cohen, 2009). CSR communication through causerelated marketing campaigns often faces consumers' disbelief and scepticism (Pomering \& Johnson, 2009). Even more - these authors state that irresponsible behaviour of organisations faces much greater attention of stakeholders than their positive initiatives.

When managing corporate reputation, businesses need some new methods and means (both in the sense of content and form) to send signals about their willingness and readiness to be a good citizen. One of the ways is the involvement of children into social 
and environmental initiatives performed by the organisation in order to demonstrate the care of children and the well-being of the society.

\section{Involvement of Children into Corporate Social and Environmental Initiatives when Developing Corporate Reputation}

From the legal viewpoint, a child is every human being under 18 , if the laws do not state otherwise. This viewpoint is followed in this research.

Traditionally children were considered as future audience, i.e. future consumers. Nowadays, more often children are named an important group of stakeholders due to their increased purchasing power and influence upon the family buying patterns and decisions (Calvert, 2008; Crane \& Kazmi, 2010; Hart et al., 2011; de la Ville, 2014; Estrela et al., 2014). When naming children stakeholders, the viewpoint is adopted that an organisation's activity can directly or indirectly influence children's welfare and / or can grant or withdraw resources that are needed for the activities of an organisation (Maignant \& Ferrel, 2004).

Most research on corporate reputation focuses on the adult subjects of the market, children are mentioned fragmentarily. In the field of reputation management, it usually is confined to the viewpoint that multinational corporations that conduct their activity in developing countries should incorporate such issues as child labour in the supply chains into their CSR policy. The systemic viewpoint of children as one of stakeholders' group is missing.

Children as stakeholders face much more attention in the field of marketing. A lot of attention is paid to the processes of the socialisation of children as consumers discloses how traditional (i.e., television commercials) and non-traditional (i.e., ads online, in social networks and integrated in video games) advertising influences children as consumers' attitudes and behaviour (Rozendaal et al., 2013; Carlson \& Clarke, 2014; An \& Kang, 2014; Simoes \& Agante, 2014). Such research is focused on the cognition of children as consumers, children's understanding of commercial content, as well as the search for ways to communicate a brand message effectively and develop loyal consumers. Some attention is paid to moral issues of advertising. However, possible influence of such activities upon an organisation's reputation is not analysed or discussed.

The penetration of everyday life of children by television and the Internet enables companies to present the intensive and convincing brand communication flow. Children and adolescents, who have neither knowledge nor the analytical skills to deal with tempting offers of companies (Bergadaa, 2007), become an easy target for business.

Thus, non-governmental organisations and researchers representing the field of marketing ethics draw the attention to the vulnerability of children as stakeholders. Business organisations are encouraged to voluntarily take responsibility for possible influence of their activities upon children's welfare instead of developing the relations with children from the brand development perspectives only. For example, producers and sellers of processed food and appetisers are encouraged to take their responsibility for the formation of unhealthy nutrition habits and increasing overweight and obesity of children (Mallarino et al., 2013).

It is possible to claim that these days children-oriented business issues draw greater attention from parents, the community and institutions taking care of the children rights 
protection. This is very important from the perspective of corporate reputation management because stakeholders form their perception about an organisation by assessing how the organisation behaves towards them and how the organisation behaves towards other stakeholders (Hillenbrand \& Money, 2007). Thus the organisation 's activities targeted at children influence consumers' and other organisation stakeholders' perception of and attitudes towards the organisation.

Referring to the above-mentioned viewpoints, children-oriented business activities and initiatives can and must be treated as a determinant of corporate reputational risk. The relationship between an organisation and children and children-related issues has to be planned and developed systematically, not only from the economical but also from the reputation risk management perspective. Reputation strategy should clearly show how many and what obligatory and voluntarily taken child-related responsibilities are initiated by an organisation.

Crane and Kazmi (2010) recommend seven corporate responsibilities to children. The children-related responsibilities involve not only moral and physical protection, the conditions of parents' employment, but also the involvement into initiatives of supporting education, strategic philanthropy, and engagement into partnership for change.

The demonstration of such child-related responsibilities has changed some direct children-oriented advertising, due to ethical issues on which discussions emerge more often. Organisations search for new ways and channels to remind children and their parents and the community about themselves, to form the impression of publicity, the reputation of a good citizen and favourability among groups of these stakeholders. One of the ways is targeting of social responsibility initiatives at schools (Calvert, 2008; Doster \& Tyrrel, 2011) and organising children-engaging social and environmental initiatives. Such green and social initiatives are usually related to the organisation 's striving to voluntarily take social and environmental responsibility, as well as to send signals to other stakeholders that the company contributes to the development of children as responsible citizens and the wellbeing of the society, as well.

\section{MATERIAL AND METHODS}

\section{Sample and Data Collection}

Children-engaging corporate social and environmental initiatives as determinants of corporate reputation are a fresh topic in the field of reputation management and they lack both theoretical and empirical investigation. Therefore, the exploratory research was chosen as an attempt to get some empirical insights and lay the groundwork for future studies.

The survey took place in Lithuania in May 2014. The data were collected by using two ways of the survey: survey-in-written and coordinated survey online.

A total of 354 filled-in questionnaires were received. A larger part of the respondents were women (79.1\%) and people with higher education. $59.6 \%$ of the respondents have under-age children. Among them, $62.4 \%$ of the respondents have at least one child younger than 6 years old; $60.4 \%$ of the respondents have at least one child at the age of $6-11 ; 58.9 \%$ of the respondents have at least one child at the age of $12-16$ years. Table 1 presents other characteristics of the sample. 
Table 1. Sample profile $(n=354)$

\begin{tabular}{|c|c|c|c|c|c|}
\hline Characteristics & Frequency & Percent & Characteristics & Frequency & Percent \\
\hline \multicolumn{6}{|l|}{ Age: } \\
\hline Up to 20 years & 18 & 5.08 & $40-49$ years & 45 & 12.71 \\
\hline $20-29$ years & 137 & 38.70 & $50-59$ years & 14 & 3.95 \\
\hline $30-39$ years & 132 & 37.29 & 60 years and more & 8 & 2.26 \\
\hline \multicolumn{6}{|l|}{ Education: } \\
\hline Secondary & 55 & 15.54 & $\begin{array}{r}\text { Higher university, bache- } \\
\text { lor }\end{array}$ & 143 & 40.40 \\
\hline Vocational & 17 & 4.80 & $\begin{array}{r}\text { Higher university, } \\
\text { master's }\end{array}$ & 104 & 29.38 \\
\hline College & 23 & 6.50 & Doctor of sciences & 12 & 3.39 \\
\hline \multicolumn{6}{|c|}{ Monthly income per household: } \\
\hline Up to $1500 \mathrm{LTL}$ & 69 & 19.49 & 3501-4500 LTL & 51 & 14.41 \\
\hline $1501-2500 \mathrm{LTL}$ & 83 & 23.45 & More than $4500 \mathrm{LTL}$ & 78 & 22.03 \\
\hline 2501-3500 LTL & 73 & 20.62 & & & \\
\hline
\end{tabular}

Source: own study.

\section{Measures}

During the research, consumers' perception of and attitudes towards companies which take children-engaging social and environmental initiatives, were surveyed.

In the beginning of the questionnaire the term social initiatives of firms was explained as actions/programmes of businesses, aimed to increase the well-being in certain groups of people (seniors at care home, children at care home and so on). In order to understand the term children-engaging social initiatives better, some examples were presented: the initiative 'Cheer on the Senior People with a Christmas Card' organised by Firm A, during which children were invited to draw cards for the residents of the senior care home. The second presented example was the initiative called 'Return an Unnecessary Toy' organised by Firm B, during which children were invited to give away unused toys to children care homes. The third example presented was the initiative 'Share A Christmas Delicacy' took by Firm C, during which children were invited to bring some chocolate, sweets or other delicacies, which together with the delicacies presented by the firm were carried to poor families.

The environmental initiatives of firms were explained as the actions of companies aimed to protect and foster nature. In order to provide better understanding of the term children-engaging environmental (or green) initiatives, the following examples were presented: the contest of children drawings 'I Sort Trash' organised by Firm D; the initiative to collect secondary raw materials at schools organised by Firm E; the contest of children drawings 'Protect Lithuanian Forests' organised by Firm F.

In order to analyse consumers' perception and attitudes, two five-point Likert scales ranging from 1 (strongly disagree) to 5 (strongly agree) were used. The first scale (Table 2) is aimed to find out consumers' perception and attitudes in respect of companies taking children-engaging social initiatives. The scale consists of eight Likert items. In the 
Table 2. The scale for measuring consumers' perception and attitudes towards companies which take children-engaging social initiatives

\begin{tabular}{|c|c|c|c|}
\hline & $\begin{array}{l}\text { Likert } \\
\text { items }\end{array}$ & & $\begin{array}{l}\text { Internal } \\
\text { consistency }\end{array}$ \\
\hline \multirow{4}{*}{ 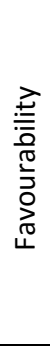 } & SI_1 & $\begin{array}{l}\text { Companies, when organising children-engaging social initiatives, } \\
\text { contribute to developing children as responsible citizens }\end{array}$ & \multirow{8}{*}{$\begin{array}{l}\text { Cronbach's } \\
\text { alpha = } \\
0.791\end{array}$} \\
\hline & SI_2 & I like children-engaging social initiatives of companies & \\
\hline & SI_3 & $\begin{array}{l}\text { I feel greater favourability towards companies organising chil- } \\
\text { dren-engaging social initiatives than towards the ones that do } \\
\text { not pay any attention to children }\end{array}$ & \\
\hline & SI_4 & $\begin{array}{l}\text { I willingly agree / would agree that my child would take part in } \\
\text { social initiatives organised by companies }\end{array}$ & \\
\hline \multirow{4}{*}{ 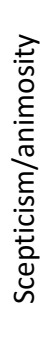 } & SI_5 & $\begin{array}{c}\text { Companies engaging children in their social initiatives pursue to } \\
\text { enlarge their profit and ignore children's interests }\end{array}$ & \\
\hline & SI_6 & $\begin{array}{l}\text { Companies should take their social initiatives by themselves and } \\
\text { not involve children in them }\end{array}$ & \\
\hline & SI_7 & $\begin{array}{c}\text { When organising children-engaging social initiatives, companies } \\
\text { behave unethically }\end{array}$ & \\
\hline & SI_8 & $\begin{array}{l}\text { I would like companies' social initiatives engaging children to be } \\
\text { more strictly limited by legal acts }\end{array}$ & \\
\hline
\end{tabular}

Source: own study.

Table 3. The scale for measuring consumers' perception and attitudes towards companies which take children-engaging environmental initiatives

\begin{tabular}{|c|c|c|c|}
\hline & $\begin{array}{l}\text { Likert } \\
\text { items }\end{array}$ & & $\begin{array}{l}\text { Internal } \\
\text { consistency }\end{array}$ \\
\hline \multirow{4}{*}{ 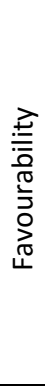 } & El_1 & $\begin{array}{c}\text { Companies, when organising children-engaging environmental } \\
\text { initiatives, contribute to developing children as responsible citi- } \\
\text { zens }\end{array}$ & \multirow{8}{*}{$\begin{array}{l}\text { Cronbach's } \\
\text { alpha = } \\
0.812\end{array}$} \\
\hline & El_2 & I like children-engaging environmental initiatives of companies & \\
\hline & El_3 & $\begin{array}{l}\text { I feel greater favourability towards companies organising chil- } \\
\text { dren-engaging environmental initiatives than towards the ones } \\
\text { that do not pay any attention to children }\end{array}$ & \\
\hline & El_4 & $\begin{array}{l}\text { I willingly agree / would agree that my child would take part in } \\
\text { environmental initiatives organised by companies }\end{array}$ & \\
\hline \multirow{4}{*}{ 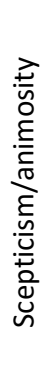 } & El_5 & $\begin{array}{l}\text { Companies engaging children into their environmental initia- } \\
\text { tives pursue to enlarge their profit and ignore children's inter- } \\
\text { ests }\end{array}$ & \\
\hline & El_6 & $\begin{array}{l}\text { Companies should take their environmental initiatives by } \\
\text { themselves and not involve children in them }\end{array}$ & \\
\hline & El_7 & $\begin{array}{l}\text { When organising children-engaging environmental initiatives, } \\
\text { companies behave unethically }\end{array}$ & \\
\hline & El_8 & $\begin{array}{l}\text { I would like companies' environmental initiatives engaging chil- } \\
\text { dren to be more strictly limited by legal acts }\end{array}$ & \\
\hline
\end{tabular}

Source: own study. 
scale, four Likert items are aimed to measure consumers' favourability in respect of companies taking children-engaging social initiatives. The other four statements pursue to measure consumers' scepticism and animosity in respect of such companies.

The second scale (Table 3 ) is aimed to disclose consumers' perception and attitudes towards companies organising children-engaging environmental initiatives. In the scale four Likert items are meant to measure consumers' favourability towards companies taking children-engaging green initiatives. Other four statements are aimed to measure consumers' scepticism and animosity towards such companies.

Referring to the Cronbach's alpha coefficients, internal consistency of both scales is good.

\section{RESULTS AND DISCUSSION}

Table 4 presents general descriptive statistics for the sample. The data shows consumers' perception and attitudes in respect of companies which organise and implement childrenengaging social and green initiatives.

The research data suggest that the respondents tend to agree that companies implementing children-engaging social and environmental initiatives contribute to developing children as responsible citizens (SI_1; EI_1). The perception and attitudes of the respondents are slightly more favourable towards companies which take children-engaging environmental initiatives, when compared to the perception of the companies which take children-engaging social initiatives.

Table 4. Perception and attitudes towards companies which take children-engaging social initiatives (SI) and environmental initiatives (EI)

\begin{tabular}{|c|c|c|c|c|c|c|}
\hline & \multicolumn{3}{|c|}{$\begin{array}{l}\text { Perception and attitudes towards the } \\
\text { companies which take children-engag- } \\
\text { ing social initiatives }\end{array}$} & \multicolumn{3}{|c|}{$\begin{array}{l}\text { Perceptions and attitudes towards the } \\
\text { companies which take children-engag- } \\
\text { ing green initiatives }\end{array}$} \\
\hline & Likert items & Median & Mode & Likert items & Median & Mode \\
\hline \multirow{4}{*}{ 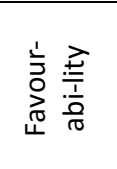 } & SI_1 & 4.00 & 4.00 & El_1 & 4.00 & 4.00 \\
\hline & SI_2 & 4.00 & 4.00 & El_2 & 4.00 & 4.00 \\
\hline & SI_3 & 3.00 & 4.00 & El_3 & 4.00 & 4.00 \\
\hline & SI_4 & 3.00 & 4.00 & El_4 & 4.00 & 4.00 \\
\hline \multirow{4}{*}{ 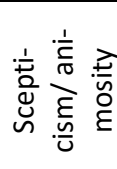 } & SI_5 & 3.00 & 3.00 & El_5 & 3.00 & 3.00 \\
\hline & SI_6 & 3.00 & 3.00 & El_6 & 3.00 & 2.00 \\
\hline & SI_7 & 3.00 & 3.00 & El_7 & 2.00 & 2.00 \\
\hline & SI_8 & 3.00 & 3.00 & El_8 & 3.00 & 3.00 \\
\hline
\end{tabular}

Source: own study.

The emotional attitudes are slightly more positive towards companies taking green initiatives (SI_3; EI_3). The research participants would more willingly agree that their children would get involved in environmental initiatives taken by companies than in social ones (SI_4; El_4).

The respondents tend to disagree that companies which take children-engaging environmental initiatives behave unethically. The better perception is about the ethical issues 
of companies taking children-engaging environmental initiatives than social initiatives (SI_7, El_7).

The respondents do not express their strict perception of the necessity to regulate children's engagement in social and green initiatives more strictly (SI_8; EI_8). Thus, it is evident that the respondents' scepticism and animosity towards companies organising children-engaging social initiatives is slightly stronger than towards companies organising children-engaging green programmes (SI_6, 7; EI_6, 7). The divergence of men's and women's opinions is presented in Table 5.

The data obtained during the research suggest that the women's perception of and attitudes towards companies that organise children-engaging social and environmental initiatives are more positive than of the men. The favourability of the women towards such companies is greater, and the animosity and scepticism is weaker.

The women more often think that such companies contribute to developing children as responsible citizens (SI_1; El_1). The women's emotional attitudes towards companies which take children-engaging social and green initiatives are also more favourable than of men (SI_2, 3; EI_2, 3). The women more willingly agree that their children would participate in such social and environmental initiatives organised by companies (SI_4; EI_4).

The animosity of the men towards companies which organise children-engaging social and environmental programmes is greater than of the women. The men-respondents are subject to agree more that companies engage children in their social and green initiatives considering their self-interested motives, i.e., they pursue to enlarge their profit not regarding children's interests (SI_5; EI_5).

The men agree more than the women with the statements that such companies behave unethically $(\mathrm{SI}$ _7, EI_7).

Table 5. Perception and attitudes of women and men towards companies which take childrenengaging social and environmental initiatives

\begin{tabular}{|c|c|c|c|c|c|c|c|c|}
\hline & \multicolumn{4}{|c|}{$\begin{array}{l}\text { Perceptions and attitudes towards } \\
\text { companies, which take children-en- } \\
\text { gaging social initiatives }\end{array}$} & \multicolumn{4}{|c|}{$\begin{array}{l}\text { Perceptions and attitudes towards } \\
\text { companies, which take children-en- } \\
\text { gaging green initiatives }\end{array}$} \\
\hline & \multirow{2}{*}{$\begin{array}{l}\text { Likert } \\
\text { items }\end{array}$} & \multicolumn{2}{|c|}{ Mean rank } & \multirow{2}{*}{$\begin{array}{c}\text { Asymp. sig } \\
\text { (2-tailed) }\end{array}$} & \multirow{2}{*}{$\begin{array}{l}\text { Likert } \\
\text { items }\end{array}$} & \multicolumn{2}{|c|}{ Mean rank } & \multirow{2}{*}{$\begin{array}{l}\text { Asymp. sig } \\
\text { (2-tailed) }\end{array}$} \\
\hline & & Women & Men & & & Women & Men & \\
\hline \multirow{4}{*}{ Favourability } & SI_1 & 186.29 & 138.42 & 0.000 & El_1 & 184.12 & 147.26 & 0.003 \\
\hline & SI_2 & 187.04 & 135.51 & 0.000 & El_2 & 185.35 & 142.08 & 0.001 \\
\hline & SI_3 & 185.37 & 141.99 & 0.001 & El_3 & 184.40 & 145.76 & 0.003 \\
\hline & SI_4 & 184.43 & 145.68 & 0.003 & El_4 & 184.55 & 145.19 & 0.002 \\
\hline \multirow{4}{*}{$\begin{array}{c}\text { Scepticism/ an- } \\
\text { imosity }\end{array}$} & SI_5 & 170.08 & 201.48 & 0.013 & El_5 & 170.26 & 200.76 & 0.002 \\
\hline & SI_6 & 169.24 & 204.74 & 0.006 & El_6 & 168.86 & 206.21 & 0.003 \\
\hline & SI_7 & 170.62 & 199.38 & 0.025 & El_7 & 168.75 & 206.75 & 0.003 \\
\hline & SI_8 & 175.51 & 180.35 & 0.076 & El_8 & 174.01 & 186.17 & 0.344 \\
\hline
\end{tabular}

Source: own study.

\section{Limitations}

In this study only the perception and attitudes of consumers was investigated. Thus, other stakeholders' (employees, NGOs, regulatory institutions, media, partners, etc.) perception 
of companies that take children-engaging CSR initiatives have not been disclosed.

More research will be required to answer the following questions: (a) how does the number of children in the family affect the parents' perception and attitudes in respect of companies that organise children-engaging social and environmental initiatives; (b) how does the age of children in the family affect the parents' perception of and attitudes towards companies organising and implementing children-engaging CSR practice; (c) what is the correlation between the stakeholders' age, education, income and their perception of companies which organise children-engaging social and environmental initiatives.

Future research should also focus on how companies producing different types of products (milk, fast food, sweets, books, toys, cars, toothpaste, etc.) are perceived by consumers when taking children-engaging CSR initiatives. It should be also empirically tested if there are any significant differences in consumers' perception of local/national companies and multinational companies which take and communicate children-engaging social and green initiatives.

In this study, the definitions of social initiatives and environmental (green) initiatives are in general. In future research it would be useful to distinguish at least three types of social and environmental initiatives - local, national, worldwide. Future research should focus on identifying stakeholders' perception and attitudes in respect of companies that organise and implement children-engaging local/national/worldwide social and environmental practice.

\section{CONCLUSIONS}

The paper makes four contributions to corporate reputation management studies. First, this study provides theoretical and empirical insights into how children-engaging social responsibility initiatives can affect building corporate reputation. The results suggest that children as a group of stakeholders need special consideration. Involving children in corporate social and environmental practice should be treated not only as an act of being a good citizen but also as a determinant of corporate reputational risk.

Second, the empirical results verify the theoretical approach that stakeholders form opinions about a company not only by assessing how the company behaves towards them, but also by assessing how the organisation treats other stakeholders. The paper extends the understanding of how business practices targeted at children may affect corporate reputation.

Third, the research results confirm the theoretical approach that the influence of CSR performance upon corporate reputation varies in applying different instruments of corporate social responsibility. The findings of the research indicate that consumers' perception and attitudes are slightly more favourable towards the companies which take childrenengaging environmental initiatives, when compared to the perception of the companies which take children-engaging social initiatives.

Lastly, the research results support the theoretical approach that the influence of CSR activity upon corporate reputation varies in different groups of stakeholders. The empirical results suggest the gender differences in perceiving CSR activities with the involvement of children. Women's perception and attitudes in respect of companies that organise children-engaging social and environmental initiatives are slightly more positive than men's. 
The animosity and scepticism of men in respect of companies which organise childrenengaging social and environmental programs are stronger than of women.

Further research should focus on exploring both consumers and other stakeholders' perception of companies that take local, national and worldwide children-engaging social and green initiatives. More research will be required to disclose not only the emotional, but also the functional value of such initiatives and their possible impact on corporate performance results.

Consumers' socio-demographic characteristics should be disclosed as determinants of consumer perceptions and attitudes in respect of companies which organise and implement children-engaging social and green initiatives. It should be empirically tested if consumers' perception and attitudes vary towards local and foreign companies taking children-engaging CSR initiatives, as well as towards companies producing different types of products.

Researchers are encouraged to empirically test how children-engaging social and environmental initiatives are perceived in the countries with different cultural and economic characteristics.

\section{REFERENCES}

An, S., \& Kang, H. (2014). Advertising or games? Advergames on the internet gaming sites targeting children. International Journal of Advertising, 33(3), 509-532. doi: 10.2501/IJA-33-3-509-532

Arendt, S., \& Brettel, M. (2010). Understanding the influence of corporate social responsibility on corporate identity, image and firm performance. Management Decisions, 48(10), 1469-1491. doi: 10.1108/00251741011090289

Babiak, K., \& Trendafilova, S. (2011). CSR and environmental responsibility: motives and pressures to adopt green management practices. Corporate Social Responsibility and Environmental Management, 18, 11-24. doi: 10.1002/csr.229

Bartikowski, B., \& Walsh, G. (2011). Investigating mediators between corporate reputation and customer citizenship behaviors. Journal of Business Research, 64(1), 39-44. doi: 10.1016/j.jbusres.2009.09.018

Bergadaa, M. (2007). Children and business: pluralistic ethics of marketers. Society and Business Review, 2(1), 5-73. doi: 10.1108/17465680710725272

Brammer, S. J., \& Pavelin, S. (2006). Corporate reputation and social performance: the importance of fit. Journal of Management Studies, 43(3), 435-455.

Calvert, S. L. (2008). Children as consumers: advertising and marketing. Future of Children, 18(1), 205-234.

Capriotti, P., \& Moreno, A. (2007). Corporate citizenship and public relations: The importance and interactivity of social responsibility issues on corporate websites. Public Relations Review, 33(1), 84-91.

Carlson, L., \& Clarke, B. (2014). Reassessing the current state of advertising to children. International Journal of Advertising, 33(3), 429-436. doi: 10.2501/IJA-33-3-429-436

Castaldo, S., Perrini, F., Misani, N., \& Tencati, A. (2009). The Missing Link between Corporate Social Responsibility and Customer Trust: The Case of Fair Trade Products. Journal of Business Ethics, 84(1), 1-15. doi: 10.1007/s10551-008-9669-4 
Cohen, J. (2009). Getting the stain out of sustainable brands. In J. Klewes \& R. Wreschniok (Eds.), Reputation Capital. Building and maintaining Trust in the 21st Century (pp. 236-248). London: Springer.

Crane, A., \& Kazmi, B. A. (2010). Business and children: Mapping impacts, managing responsibilities. Journal of Business Ethics, 91(4), 567-586. doi: 10.1007/s10551-009-0132-y

Crittenden, V. L., Crittenden, W. F., Pinney, C. C., \& Pitt, L. F. (2011). Implementing global corporate citizenship: An integrated business framework. Business Horizons, 54(5), 447-455. doi: 10.1016/j.bushor.2011.04.006

Dawkins, J. (2004). Corporate responsibility: the communication challenge. Journal of Communication Management, 9(2), 108-119.

De La Ville, V. I. (2014). Young people as company stakeholders? Moving beyond CSR... Young Consumers, 15(1), 3-16.

Deng, X., Kang, J., \& Low, B. S. (2013). Corporate social responsibility and stakeholder value maximization: Evidence from mergers. Journal of Financial Economics, 110(1), 87-109. doi: 10.1016/j.jfineco.2013.04.014

Doster, L., \& Tyrrell, J. M. (2011). Marketing communications in the classroom: The parents' view. Journal of Marketing Communications, 17(1), 1-15.

Estrela, R. C., Pereira, F. C., \& Ventura, J. B. (2014). Children's socialization in consumption: the role of marketing. EuroMed Journal of Business, 9(3), 222-251. doi: 10.1108/EMJB-10-2013-0051

Gibbs, C. (2012). Corporate citizenship and corporate environmental performance. Crime, Law and Social Change, 57, 345-372. doi: 10.1007/s10611-012-9365-2

Green, T., \& Peloza, J. (2011). How does corporate social responsibility create value for consumers? Journal of Consumer Marketing, 28(1), 48-56.

Graafland, J. J. (2004). Collusion, reputation damage and interest in code of conduct; the case of Dutch construction company. Business Ethics: A European Review, 2-3(13), 127-142.

Hart, J., Paludan., M. B., Steffen, L., \& O'Donoghue, G. (2011). Working with children as stake-holders in development: the challenges of organizational change. Development in Practice, 21(3), 330342. doi: $10.1080 / 09614524.2011 .558066$

Hillenbrand, C., \& Money, K. (2007). Corporate responsibility and corporate reputation: Two separate concepts or two sides of the same coin? Corporate Reputation Review, 10(4), 261-277.

Lin, C. P, Tsai, Y. H., Joe, S. W., \& Chiu, C. K. (2012). Modelling the relationship among perceived corporate citizenship, firms' attractiveness, and career success expectation. Journal of Business Ethics, 105(1), 83-93. doi: 10.1007/s10551-011-0949-z

Linthisum, C., Reitenga, A. L., \& Sanchez, J. M. (2010). Social responsibility and corporate reputation: The case of the Arthur Andersen Enron audit failure. Journal of Accounting and Public Policy, 29(2), 160-176.

Lynes, J. K., \& Andrachuk, M. (2008). Motivations of corporate social and environmental responsibility: A case study of Scandinavian Airlines. Journal of International Management, 14(1), 377-390. doi: 10.1016/j.intman.2007.09.004

Maden, C., Arikan, E., Telci, E. E., \& Kantur, D. (2012). Linking corporate social responsibility to corporate reputation: a study understanding behavioral consequences. Procedia-Social and Behavioural Sciences, 58(1), 655-664. doi: 10.1016/j.sbspro.2012.09.1043

Maignan, I., \& Ferrell, O. C. (2004). Corporate social responsibility and marketing: An integrative framework. Journal of the Academy of Marketing Science, 32(1), 3-19. 
Mallarino, C., Gomez, L. F., Gonzalez-Zapata, L., Cadena, Y., \& Perra, D. C. (2013). Advertising of ultraprocessed foods and beverages: children as a vulnerable population. Revista De Saude Publica, 47(5), 1006-1010. doi: 10.1590/s0034-8910.2013047004319

Mehtap, O., \& Kokalan, O. (2012). The relationship between corporate reputation and organizational citizenship behaviour: a comparative study on TV companies and banks. Quality \& Quantity, 47(1), 3609-3619.

Orlitzky, M., Siegel, D. C., \& Waldman, D. A. (2011). Strategic corporate social responsibility and environmental sustainability. Business \& Society, 50(1), 6-27.

Pomering, A., \& Johnson, L. W. (2009). Constructing a corporate social responsibility reputation using corporate image advertising. Australiasian Marketing Journal, 17, 106-114. doi: 10.1016/j.ausmj.2009.05.006

Rego, A., Leal, S., Cunha, M. P., Faria, J., \& Pinho, C. (2010). How the perceptions of five dimensions of corporate citizenship and their inter-inconsistencies predict affective commitment. Journal of Business Ethics, 94(1), 107-127. doi: 10.1007/s10551-009-0252-4

Rozendaal, E., Slot, N., van Reijmersdal, E. A., \& Buizen, M. (2013). Children's responses to advertising in social games. Journal of Advertising, 42(2-3), 142-154. doi: 10.1080/00913367.2013. 774588

Shinkle, G. A., \& Spencer, J. W. (2012). The social construction of global corporate citizenship: Sustainability reports of automotive corporations. Journal of World Business, 47(1), 123-133. doi: 10.1016/j.jwb.2011.02.003

Simoes, I., \& Agante, L. (2014). The impact of event sponsorship on Portuguese children's brand image and purchase intentions. The moderator effects of product involvement and brand familiarity. International Journal of Advertising, 33(3), 533-556. doi: 10.1590/S00348910.2013047004319

Sison, A. J. G. (2009). From CSR to corporate citizenship: Anglo-American and Continental European perspectives. Journal of Business Ethics, 89(1), 235-246.

Smaiziene, I., \& Jucevicius, R. (2009). Corporate reputation: multidisciplinary richness and search for a relevant definition. Inzinerine Ekonomika - Engineering Economic, 62(2), 91-101.

Smaiziene, I., \& Jucevicius, R. (2013). Structural composition of a corporate reputation portfolio (Sustainable development perspective). International Journal of Business and Management, 8(15), 44-56. doi: 10.5539/ijbm.v8n15p44

Timonen, L., \& Luoma-aho, V. (2010). Sector-based corporate citizenship. Business Ethics: A European Review, 19(1), 1-13. doi: 10.1111/j.1467-8608.2009.01575.x

Tracey, P., Phillips, N., \& Haugh, H. (2005). Beyond Philanthropy: Community Enterprise as a Basis for Corporate Citizenship. Journal of Business Ethics, 58, 327-344.

Truscott, R. A., Bartlett, J. L., \& Tywoniak, S. A. (2009). The reputation of the corporate social responsibility industry in Australia. Australasian Marketing Journal, 17(1), 84-91. doi: 10.1016/j.ausmj.2009.05.001

Veleva, V. R. (2010). Managing corporate citizenship: A new tool for companies. Corporate Social Responsibility and Environmental Management, 17(1), 40-51. doi: 10.1002/csr.206

Vilanova, M., Lozano, J., \& Arenas, D. (2009). Exploring the nature of the relationship between CSR and competitiveness. Journal of Business Ethics, 87(1), 57-69. 


\section{Author}

\section{Ingrida Šmaižienè}

A lecturer at the Department of Strategic Management, Kaunas University of Technology since 2009. PhD student in Management (Kaunas University of Technology). Main fields of scientific interests are corporate reputation management, reputational capital, country image and branding, and made-in image. The study subjects delivered: Image and Reputation, Entrepreneurship, Business research methods.

\section{Correspondence to:}

Ingrida Smaiziene

Kaunas University of Technology

School of Economics and Business

K. Donelaicio str. $20-411$, LT-49440 Kaunas, Lithuania

ingrida.smaiziene@gmail.com

\section{Copyright and License}

This article is published under the terms of the Creative Commons Attribution - NonCommercial - NoDerivs (CC BY-NC-ND 3.0) License http://creativecommons.org/licenses/by-nc-nd/3.0/

Published by the Centre for Strategic and International Entrepreneurship - Krakow, Poland 